\title{
Technical Services Job Ads: Changes Since 1995
}

\section{JoAnne Deeken and Deborah Thomas}

\begin{abstract}
For this project, the researchers studied job ads posted during 2001 in American Libraries, Autocat, The Chronicle of Higher Education, College and Research Libraries News, and SerialsST. This article replicates studies by Penny M. Beile and Megan M. Adams, and Michael Towsey that analyzed job ads from the mid-1990s. ${ }^{1-2}$ The results from the current study were compared with their results. Findings included a very large increase in the number of jobs advertised, increases in the number of jobs reposted and in salaries, and a decrease in foreign-language requirements.
\end{abstract}

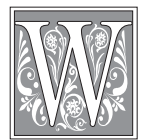

hen talking to colleagues, the anecdotal consensus seems to be that technical service jobs are becoming increasingly hard to fill. They report that pools for their jobs are small and that re-advertising positions is not uncommon. Have the requirements for jobs in technical services changed? What qualifications are necessary to obtain a professional position in technical services? What is the current job market? The purpose of this study was to answer those questions by replicating past studies.

\section{Review of the Literature}

There has been a long history of tracing changes in technical services jobs by examining job ads. Beverly P. Lynch and Kimberley Robles Smith's content analysis of job ads that appeared in College $\mathcal{E}$ Research Library News between 1973 and 1998 highlighted several trends in the profession. ${ }^{3}$ They saw a growing demand for behavioral skills, especially oral and written communication skills, in jobs at all levels. Information technology skills were required for jobs in all areas. Most jobs required an ALA-accredited MLS.

David W. Reser and Anita P. Schuneman did a comprehensive content analysis of the academic job market, comparing jobs in public and technical services. ${ }^{4}$ Their study showed that public services jobs were more likely to require advanced degrees. Technical services jobs required more experience and computer skills, and were more likely to require knowledge of a foreign language.

Michael Towsey did a content analysis of cataloging vacancies advertised between March 1995 and February 1996 in the United States and the United Kingdom with the goal of discovering trends in cataloging employment. ${ }^{5}$ Towsey concluded that the demand for catalogers has declined in the U.S. since the late 1980s and that the trend in the U.K. is toward temporary positions for catalogers. The study indicated that employers sought 
traditional cataloging skills performed in an online environment.

Penny M. Beile and Megan M. Adams updated the Reser and Schuneman study in 1996 by using the same criteria to examine 900 job advertisements published in four journals. ${ }^{6}$ Beile and Adams found a significant decrease in the number of jobs advertised. Technical services jobs experienced the most significant losses, with cataloging jobs showing the greatest decrease. Although technical services jobs were decreasing, Beile and Adams reported increases in the number of "specialist" positions, such as positions in electronic services.

In a 2000 master's paper for the University of North Carolina, Mihoko Hosoi analyzed advertisements appearing in 1999 College $\mathcal{E}$ Research Libraries News and American Libraries to identify required qualifications for academic cataloging positions. ${ }^{7}$ Hosoi found that most cataloging postings required at least one year of work experience and involved some kind of special cataloging expertise, such as foreign-language cataloging, specialformats cataloging, or serials cataloging. Supervisory skills also were considered important, with 20 percent of advertisements listing it as a requirement. Noncataloging activities such as reference or collection development were primarily listed as job responsibilities rather than requirements.

William Fisher researched the development of electronic resources librarian positions by analyzing job ads posted in American Libraries between 1985 and 2001. ${ }^{8}$ The study concluded that knowledge of public services functions is critical to this job, as is the knowledge of available technologies. Communication skills also were found to be of the highest importance.

Zahiruddin Khurshid's 2003 job analysis content study assessed the impact of information technology (IT) on job requirements and qualifications for catalogers. ${ }^{9}$ His study concluded that IT has had a major impact on the skills required of catalogers and that many catalog- ers are involved in the former domains of systems and automation librarians. Common job requirements included familiarity with integrated library systems, experience with bibliographic utilities, and knowledge of metadata schemes and tools.

\section{Hypotheses}

This study focused on technical services job ads to identify changes between past and current jobs and to identify possible trends for the future. The hypotheses were:

- The negative trend in demand for technical services jobs had reversed.

- There is a marked increase in the demand for computer skills.

- Entry-level technical services jobs are rare. Most vacancies require prior technical services experience.

- Technical services jobs are hard to fill. Measures would include an increase in reposts, an increase in ads for temporary and part-time positions, and a decrease the requirement for an MLS.

The study authors were very curious about salaries, though they had no preconceived idea of whether salaries had remained the same, increased, or decreased. Thus, no hypothesis was drawn regarding salary trends. The two authors had opposing hypotheses on the trend for decreasing demand for foreignlanguage skills.

\section{Methodology}

The research for this study built on elements contained in two previous studies (Beile and Adams in 2000 and Towsey in 1997) with a few noteworthy differences. The Beile and Adams study was much broader and compared jobs in technical services with public services jobs. ${ }^{10}$ The work of this study focused only on technical services positions and used the Beile and Adams findings as a comparison to track the evolution of technical services jobs. Michael Towsey analyzed advertisements for cataloging positions in both the U.S. and the U.K. in all types of libraries. ${ }^{11}$ 
This study's authors collected data only on U.S. academic libraries but expanded the study to include all technical services jobs, not just cataloging positions. Because they chose not to replicate previous studies exactly, the study authors used great care in comparing data. For example, when salary findings were compared with Towsey's, only cataloging salaries in the U.S. were compared. With Beile and Adams, the authors were able to compare salaries against more categories of technical services jobs.

This study considered the following job types to be technical services: cataloging, acquisitions, metadata, audiovisual cataloging, language cataloging, serials, head (or any equivalent term) of either a particular division inside technical services or all of technical services, authority control, preservation, database maintenance, and electronic resources. To compare with Towsey and Beile and Adams, the data in advertised positions were grouped into the following job categories: job responsibilities, job permanence, full- or part-time employment, work experience, languages, computer skills, supervisory requirements, and salaries. ${ }^{12-13}$ A job was defined as head of technical services if the title included those words. In addition, a job was categorized as head of technical services if the job description included direct supervision of at least two of the tech services units of cataloging, serials, or acquisitions and did not report to a head (or equivalent title such as associate dean) of technical services. A job that had combined responsibility for several of the traditional technical services functions, but only for a particular material format (e.g., head of video acquisitions and cataloging), was not considered to be a head of technical services.

Position announcements were collected from both print and electronic sources: American Libraries, Autocat, Chronicle of Higher Education, College and Research Libraries News, and SerialsST. When designing our study, the authors planned to include Acqnet, but this listserv retains job ads for only one year and the data had been deleted from the archives when the authors tried to access it.

Microsoft Access was used to collect the data in four tables with a common linking field.

The Jobs table recorded the name of the academic institution, the job title, whether the job was permanent or temporary, whether the job was full- or parttime, whether the job was tenure track, and the minimum and maximum salary ranges. It was assumed that jobs were full-time and permanent unless otherwise indicated in the advertisement. The Job Ads table recorded where and when the position was advertised and whether it was a repost. The Job Description table recorded the type of technical services job and whether the job had collection development, public services, or other library responsibilities. The final table, Job Requirements, tracked various required and preferred attributes, including degrees, work experience, languages, and other miscellaneous qualities.

The authors encountered an unexpected problem when entering data. A significant number of advertisements simply listed the job title and the school and stated that the full position description was posted on a Web site. Many of those Web sites were no longer available to consult when the study was done, so those jobs were reluctantly excluded. It is estimated that approximately 10 percent of the total job ads were in this category. If the trend continues, the validity of this type of study in the future could become suspect.

\section{Findings and Discussion}

Numbers and Sources of Job Advertisements The authors included 482 unique ads in the study. Many of them were listed in multiple sources. The source that listed the most jobs was the Chronicle of Higher Education. Of the jobs studied, 363 were listed in that publication as well as most of the ads that had been discounted because 


\begin{tabular}{|l|r|r|r|r|r|}
\hline \multicolumn{7}{|c|}{ TABLE 1 } \\
\hline Number of Ads per Publication \\
\hline & $\begin{array}{l}\text { Chronicle } \\
\text { of Higher } \\
\text { Education }\end{array}$ & Autocat & $\begin{array}{c}\text { C\&RL } \\
\text { News }\end{array}$ & $\begin{array}{c}\text { American } \\
\text { Libraries }\end{array}$ & SerialsST \\
\hline Total number of ads not reposts & 346 & 201 & 144 & 146 & 106 \\
\hline Number of reposted ads & 17 & 36 & 3 & 7 & 9 \\
\hline
\end{tabular}

of dysfunctional Web links. The source with the least number of ads was SerialsST, which had 117 ads. It is interesting that a listserv, Autocat, had the second highest number of ads. (See table 1.)

One of the most obvious results of this study in comparison to the Beile-Adams study in 1996 was the huge growth in the number of positions. ${ }^{14}$ In the 1996 study, only 199 job ads were discovered for technical services positions compared to 481 in this study, with another 10 percent discounted for lack of information. The Towsey study found 147 academic library cataloging jobs listed in U.S. publications. ${ }^{15}$ This study found 256 jobs with cataloging as the main focus. Of those, only 62 were listed exclusively in AutoCat, which Towsey did not include

\begin{tabular}{|l|r|}
\hline \multicolumn{2}{|c|}{$\begin{array}{c}\text { TABLE 2 } \\
\text { Breakdown of Types of } \\
\text { Jobs Advertised }\end{array}$} \\
\hline \hline Acquisitions & 37 \\
\hline Authority control & 6 \\
\hline Cataloging & 211 \\
\hline Electronic resources & 10 \\
\hline Head, acquisitions & 16 \\
\hline Head, cataloging & 42 \\
\hline Head, electronic resources & 3 \\
\hline Head, processing & 1 \\
\hline Head, serials & 18 \\
\hline Head, technical services & 83 \\
\hline Metadata librarian & 5 \\
\hline Preservation & 4 \\
\hline Serials & 39 \\
\hline Undesignated technical services & 6 \\
\hline
\end{tabular}

in his study. The authors assume these jobs would have been listed in one of the other publications if the listserv were not so prominent, but it is impossible to know for sure.

The number of reposted ads also was studied. Ten percent ( 49 ads) were found to be reposts, in comparison to Towsey's figure of 4 percent. ${ }^{16}$ This tends to support the hypothesis about the difficulty in filling positions as measured by reposts. However, because it is free to repost on listservs and most of the reposts were in listservs, cost may have been a factor.

Towsey also looked at employment type. ${ }^{17} \mathrm{He}$ found 1 percent of the ads were for part-time positions. In their studies of ads for 2001, the authors also found that 1 percent of the ads were for part-time positions. The authors found that approximately 5 percent of the ads were for temporary positions, compared to Towsey's finding of 7 percent. Thus, the hypothesis that there was an increase in both part-time and temporary positions was not supported by the data.

\section{Type of Jobs Advertised}

Cataloging positions were the most common jobs advertised. Adding together the head of cataloging positions and the cataloging (nonadministrative) positions, 253 of the 482 ads (58\%) were cataloging related. This percentage is the same as that found by Beile and Adams. Of the 199 ads they studied, 115 (58\%) were cataloging. ${ }^{18}$

Only 53 acquisitions positions were advertised. There may be two explanations for this paucity of ads. The first is that the inaccessibility of Acqnet affected the number of ads. William Fisher found 
52 acquisitions ads in one year of American Libraries plus the last quarter of 1999 in Acqnet and Chronicle of Higher Education. ${ }^{19}$ His data lend support to this interpretation. The alternate interpretation is that the small number of advertisements indicates that acquisitions positions are no longer considered professional. Local advertisement for staff-level positions is the norm. One of the defining characteristics of a profession is a "lock" on specialized knowledge. ${ }^{20}$ With the rise of the Internet and the increase in globalization, the lock on specialized acquisitions information is lessening or nonexistent. A de-professionalization would be expected in those circumstances. (See table 2.)

\section{Salaries}

Our discussion is of salaries listed in position ads, not of actual salaries paid. In order to compare with the two prior studies, the authors chose to study minimum salaries. David W. Reser and Anita P. Schuneman found 85 percent of their studied ads had listed salaries. ${ }^{21}$ Towsey's

\begin{tabular}{|l|c|r|r|}
\hline \multicolumn{4}{|c|}{ TABLE 4 } \\
Salaries of Those without Administrative \\
Responsibilities \\
\hline \hline Area of Position & $\begin{array}{c}\text { Mean } \\
\text { Salary }\end{array}$ & $\begin{array}{l}\text { Standard } \\
\text { Deviation }\end{array}$ & Count \\
\hline Acquisitions & $\$ 36,052$ & $\$ 8,680$ & 14 \\
\hline Authority control & $\$ 36,040$ & $\$ 3,965$ & 3 \\
\hline Cataloging & $\$ 35,349$ & $\$ 5,615$ & 123 \\
\hline Electronic resources & $\$ 37,865$ & $\$ 6,365$ & 8 \\
\hline Metadata & $\$ 41,549$ & $\$ 6,604$ & 4 \\
\hline Preservation & $\$ 45,333$ & $\$ 2,416$ & 3 \\
\hline Serials & $\$ 34,994$ & $\$ 6,029$ & 24 \\
\hline $\begin{array}{l}\text { Undesignated technical } \\
\text { services }\end{array}$ & $\$ 32,953$ & $\$ 3,849$ & 3 \\
\hline
\end{tabular}

study showed 74.5 percent of the ads had listed salaries.22 At 59 percent, the current study shows a definite decline in ads with listed salaries. Although the authors chose to include salaries as a measure of importance in this report, the measures should be considered merely indicative of trends.

The authors calculated counts, means, and standard deviations for various categories of positions. The mean salary for all the ads that included salaries was $\$ 38,688$, with a standard deviation of $\$ 9,820$. Of note is the relatively small numbers in each category and the wide standard deviations. These factors further demonstrate that the current study findings are indicative of trends and not descriptive of actual salaries.

The first salaries examined were those in administrative positions. These show ranges from $\$ 46,634$ for head of technical services to $\$ 38,078$ for head of serials. (See table 3.)

By far, the largest number of ads for nonadministrative jobs was in cataloging. These jobs had among the lowest average salaries. Only 24 acquisitions positions had listed salaries. Of these, 10 (42\%) were for heads of the department. These data support the 
Technical Services Job Ads: Changes Since 1995141

idea that, at least in acquisitions, there are fewer nonsupervisory professional positions. (See table 4.)

There was a substantial increase in salaries listed in job ads between 1996 and 2001. Beile and Adams showed an average minimum salary of $\$ 30,751$ for

\begin{tabular}{|l|r|r|}
\hline \multicolumn{3}{|c|}{ TABLE 5 } \\
Work Experience \\
\hline \hline Ads & Number & Percentage \\
\hline Ads requiring experience & 294 & 61 \\
\hline Ads preferring experience & 79 & 16 \\
\hline $\begin{array}{l}\text { Ads with no experience } \\
\text { mentioned }\end{array}$ & 109 & 23 \\
\hline
\end{tabular}
all technical services job ads; the current study found $\$ 38,688$. $^{23}$ They found the average minimum salary for a nonadministrative cataloging job was $\$ 28,888$; this study found $\$ 35,304 . .^{24}$ For cataloging job ads with administrative duties, their finding was $\$ 34,997$; this study's was $\$ 41,403 .{ }^{25}$ According to the American Institute for Economic Research's Cost of Living Calculator, the cost of living between 1996 and 2001 increased 12.87 percent. ${ }^{26}$ All the salary increases for technical services job ads exceeded this rate of growth.

The number of advertised positions, the number of reposted jobs, and the large increase in salaries all point to a change in the demand-supply ratio for technical services positions. Either more technical services librarians are needed to perform the equivalent work or the number of librarians willing to do that work has decreased. The entire body of literature dealing with technical services over the past several years points to the increase of outsourcing, the decrease in professional positions, and the increased responsibilities of nonlibrarian catalogers. Therefore, these data indicate that fewer librarians are willing to do technical services work, a decrease in supply.

\section{Work Experience}

Each job ad was coded to determine whether previous work experience was required or preferred. A total of 294 ads $(60.9 \%)$ required some kind of previous work experience, a decrease from the 64.3 percent found by Beile and Adams. ${ }^{27}$ Ninety of the ads in the current study had both required and preferred experience requirements. For the purpose of this

study, these 90 were included only in the required category. (See table 5.)

For jobs that required experience, 87 did not specify a time period. Nineteen jobs required fewer than two years, 70 required a minimum of two years, 79 required a minimum of three years, 6 required four or more years, 26 required five or more years, and 7 required six to ten years.

Seventy-nine $(16.3 \%)$ of the position announcements preferred previous work experience. This figure compares to the 16.6 percent reported by Beile and Adams. ${ }^{28}$ Of those positions, 49 did not specify a time period, 9 required one year or less, 11 asked for two years, 4 preferred three years, and 6 asked for four to eight years. Only 109 job advertisements $(22.6 \%)$ neither required nor preferred experience. The small number of technical services jobs available to librarians without experience is worth noting.

After examining job ads, the authors thought it would be interesting to also study the relationship between the mean salaries of jobs that had either preferred or required experience and those with no experience listed. (See table 6.)

Salaries are higher almost across the board for the positions requiring experience. For all jobs, the difference in salary was 6 percent. Interestingly, the difference in the salaries listed for administrative job ads requesting experience did not show as great a difference as did the salaries for nonadministrative positions ads. It is possible that most administrative-level jobs do require experience, but that requirement was not visible in the ads. 


\section{Degree Requirements}

Ninety-three percent of jobs analyzed required an MLS graduate degree. This is higher than the 90.6 percent that Beile and Adams reported. ${ }^{29}$ Only seven ads required an undergraduate degree with no MLS. An MLS/MIS from an accredited ALA program remains the one core requirement for the great majority of professional positions in technical services.

When considering preferences for advanced degrees (subject master's, law, and doctoral degrees), 18 percent of job ads expressed a preference for advanced degrees. Beile and Adams found that only 8.5 percent of technical services postings preferred an advanced degree. ${ }^{30}$

\section{Foreign-Language Requirements}

Job postings were coded for mention of foreign-language skills, whether these skills were required or preferred, and for the type of technical services job. Only 76 $(14 \%)$ of advertisements required a foreign language, and most of these ads (67 of the 76) were for cataloging positions. An additional 87 (18\%) of announcements preferred language skills. Twenty-three ads had both required and preferred foreign-language requirements and 21 of these were cataloging. (See table 7.)

A working knowledge of a foreign language appears sufficient for technical services positions, even for cataloging. Only six jobs required "fluency" or "proficiency"; four of those jobs were for cataloging jobs. Fourteen jobs asked for "bibliographic knowledge" or "working knowledge"; all these jobs were cataloging positions. Another 21 ads asked for reading knowledge; 19 of these jobs were cataloging jobs. It appears that language skills, though highly desirable in cataloging positions (over half of the 121 cataloging jobs required foreign-language knowledge), are not critical to jobs in acquisitions, serials, or other technical services areas.

Overall, little change was found in foreign-language requirements for all types of technical services jobs. Beile and Adams reported that 31 percent of technical services ads required or preferred foreign-language skills; the current study result is 34 percent. ${ }^{31}$ However, a change was found over time in language requirements for cataloging positions. Kenneth Furuta's study of cataloging job ads of the 1970s and 1980s reported that 65 percent of position announcements desired foreign-language expertise. ${ }^{32}$ Towsey's analysis of cataloging position announcements of the mid1990s showed a decline 


\begin{tabular}{|l|c|c|l|}
\hline \multicolumn{4}{|c|}{ TABLE 7 } \\
Foreign-Language Requirements \\
\hline \hline & Number & Percentage & \\
\hline Not listed & 341 & 71 & \\
\hline Preferred & 87 & 18 & \\
\hline Required & 76 & 16 & $\begin{array}{l}67 \text { of these } \\
\text { are cataloging }\end{array}$ \\
\hline
\end{tabular}

in that foreign-language skills were requested in $44 \%$ percent of cataloging positions. ${ }^{33}$ For cataloging positions, the current study shows an increase to 64 percent, equivalent to the demand in the 1970s. Towsey's data may have been a temporary fluke, or the current data once again may be showing the effects of an aging pool. (See table 8.)

\section{Computer Skills}

The authors quickly realized that collecting data on computer skills was meaningless. They had hypothesized that the data would show a large increase in the percentage of jobs requiring computer skills. Virtually every advertisement expected basic computer skills, with most requiring familiarity with Office Suite of products and some familiarity with OCLC and an ILS. It was decided that computer skills should be considered a "given" for any technical services job.

\section{Conclusion}

The data and their analysis showed mixed support of the current study's hypotheses. The first hypothesis was that the negative trend in demand for technical services jobs had reversed. Past articles had shown cataloging job ads had been declining since the 1980s and sharply dropped in the mid-1990s. ${ }^{34-35}$ The authors of the current study examined data over an equivalent, but more recent, time period. The data showed increases in the numbers of all types of technical services job ads. The downward turn in the availability of technical services jobs from the 1980s to the mid-1990s was not reflected in the data from 2001.
The data on the increase in position postings is consistent with the trends concerning aging documented by Stanley J. Wilder. He demonstrated that technical services librarians (especially catalogers) were among the oldest in the profession. In 2000,32 percent of all catalogers were age 55 or over, ${ }^{36}$ and 16 percent were over age $60 .{ }^{37}$ As technical services librarians retire, a large increase in positions ads would be expected. The data document such an increase.

The second hypothesis was that analysis of the job ads in 1991 would show a marked increase in the demand for computer skills from past studies. Beile and Adam, Towsey, and Reser and Schuneman all showed an increasing demand for computer skills. ${ }^{38-40}$ The current data showed 100 percent of ads required some computer use. Clearly, computer skills are an integral part of technical services positions in this century.

The third hypothesis was that entry-level technical services jobs are rare. The data show strong support for previous work experience in technical services. These findings are consistent with Wilder, Ingrid Hsieh-Yee, and Janet Swan Hill. Wilder shows a decrease in staffing in technical services professional positions and posits a decrease in library school coverage of cataloging. ${ }^{41}$ HsiehYee shows that discussion of cataloging concepts in basic, required library school courses has increased between 1997 and 2002, but that courses that train librarians in MARC cataloging have

\begin{tabular}{|c|c|c|}
\hline \multicolumn{3}{|c|}{$\begin{array}{c}\text { TABLE } 8 \\
\text { Foreign-Language Skills } \\
\text { (Required or Preferred) }\end{array}$} \\
\hline & $\begin{array}{c}\text { All Tech Serv } \\
\text { Job Ads }\end{array}$ & $\begin{array}{c}\text { Cataloging } \\
\text { Job Ads }\end{array}$ \\
\hline Beale and Adams & $61(31 \%)$ & \\
\hline Towsey & & $79(44 \%)$ \\
\hline Current Study & $163(34 \%)$ & $163(64 \%)$ \\
\hline
\end{tabular}


decreased..$^{42}$ Hill agrees with her and stresses the importance of local training in basic cataloging skills. ${ }^{43}$ The current data suggest that libraries do not have the time or experienced staff necessary to train catalogers. Libraries must hire more experienced catalogers.

The final hypothesis was that the requirements of technical services jobs make them hard to fill. Three measures were considered for "hard to fill": an increase in reposts, an increase in temporary and part-time positions advertised, and a decrease in the requirement for an MLS. Only the first of these measures was supported by the current data.

The studies cited in this paper showed technical services to be a highly attractive career path for librarians in the 1970s, with a steady decline since then. Does the current data actually show a reversal of that decline? What made technical services so important in the 1970s? Is that being replicated today? Hill and Deeken point out that technical services were at the cutting edge of change and technology in the 1970s and 1980s. ${ }^{44-45}$ Technical services librarians were creating standards and ap- plying them in new computerized catalogs and networks. Hill and Hsieh-Yee speak in terms of metadata librarians in the twentyfirst century but continue to stress the importance of traditional cataloging. ${ }^{46-47}$ Dilys E. Morris and Gregory Wool observe, and Hsieh-Yee's data confirm, that library schools do not believe that practical skills such as cataloging should be taught in graduate level courses. ${ }^{48-49}$ Wilder believes that many of the traditional duties of technical services librarians have been bypassed by technology. ${ }^{50}$

The technical services librarians at the University of Tennessee would like to move toward more innovative activities such as metadata and electronic resource management systems but are constrained by lack of time and staff. Are we tied to the past by integrated library systems and lack of staff? Or, are we ready for the next "golden age" of technical services? Is the increase in demand for technical services librarians found in the current study a fluke caused by massive retirements or indicative of libraries caught between different ways of acquiring and providing access to material? Only time will tell.

\section{Notes}

1. Penny M. Beile and Megan M. Adams, "Other Duties as Assigned: Emerging Trends in the Academic Library Job Market," College \& Research Libraries 61 (July 2000): 336-47.

2. Michael Towsey, "Nice Work If You Can Get It? A Study of Patterns and Trends in Cataloguing Employment in the USA and the UK in the Mid-1990s," Cataloging and Classification Quarterly 24 (1997): 61-79.

3. Beverly P. Lynch and Kimberley Robles Smith, "The Changing Nature of Work in Academic Libraries," College E Research Libraries 62 (Sept. 2001): 407-20.

4. David W. Reser and Anita P. Schuneman, "The Academic Library Job Market: A Content Analysis Comparing Public and Technical Services," College E Research Libraries 53 (Jan. 1992): 49-59.

5. Towsey, "Nice Work If You Can Get It?"

6. Beile and Adams, "Other Duties as Assigned."

7. Mihoko Hosoi, "Cataloging Positions in U.S. Academic Libraries: An Analysis of Job Advertisements, 1999" (Master's thesis, Univ. of North Carolina, 2000).

8. William Fisher, “The Electronic Resources Librarian Position: A Public Services Phenomenon?" Library Collections, Acquisitions, E Technical Services 27 (2003): 3-17.

9. Zahiruddin Khurshid, "The Impact of Information Technology on Job Requirements and Qualifications for Catalogers," Information Technology and Libraries 22 (Mar. 2003): 18-21.

10. Beile and Adams, "Other Duties as Assigned."

11. Towsey, "Nice Work If You Can Get It?"

12. Ibid.

13. Beile and Adams, "Other Duties as Assigned."

14. Ibid.

15. Towsey, "Nice Work If You Can Get It?" 
16. Ibid.

17. Ibid.

18. Beile and Adams, "Other Duties as Assigned."

19. William Fisher, "Core Competencies for the Acquisitions Librarian," Library Collections, Acquisitions and Technical Services 25 (2001): 179-90. Note that Mr. Fisher was studying ads for a different purpose and included nonacademic ads.

20. "professions," A Dictionary of Sociology, ed. Gordon Marshall (Oxford University Press, 1998). Oxford Reference Online, Oxford University Press, University of Tennessee-Knoxville. Available online at http://www.oxfordreference.com/views/ENTRY.html?subview=Main\&entry=t88. e1802.

21. Reser and Schuneman, "The Academic Library Job Market."

22. Towsey, "Nice Work If You Can Get It?"

23. Beile and Adams, "Other Duties as Assigned.

24. Ibid.

25. Ibid

26. See http://www.aier.org/cgi-aier/cocalculator.cgi.

27. Beile and Adams, "Other Duties as Assigned."

28. Ibid.

29. Ibid.

30. Ibid.

31. Ibid.

32. Kenneth Furuta, "Impact of Automation on Professional Catalogers," Information Technology and Libraries 9, no. 3 (Sept. 1990): 242-52.

33. Towsey, "Nice Work If You Can Get It?"

34. Ibid.

35. Beile and Adams, "Other Duties as Assigned."

36. Stanley J. Wilder, "New Hires in Research Libraries: Demographic Trends and Hiring Priorities," ARL Bimonthly Report 221 (Apr. 2002): 5-8.

37. - " Demographic Trends Affecting Professional Technical Services Staffing in ARL Libraries," Cataloging and Classification Quarterly 34, no 1-2 (2002): 53-57.

38. Beile and Adams, "Other Duties as Assigned."

39. Towsey, "Nice Work If You Can Get It?"

40. Reser and Schuneman, "The Academic Library Job Market."

41. Wilder, " Demographic Trends Affecting Professional Technical Services Staffing in ARL Libraries."

42. Ingrid Hsieh-Yee, "Cataloging and Metadata Education in North American LIS Programs," Library Resources and Technical Services 48 (Jan. 2004): 59-68.

43. Janet Swan Hill, "Education and Training of Catalogers: Obsolete? Disappeared? Transformed? -Part 1." Technicalities 24, no. 1 (2004): 1,10-15

44. Ibid.

45. JoAnne Deeken, "Technical Services: A New Golden Age" (Paper presented at the Tennessee Library Association, April 2003).

46. Hill, "Education and Training of Catalogers."

47. Hsieh-Yee, "Cataloging and Metadata Education in North American LIS Programs."

48. Dilys E. Morris and Gregory Wool, "Cataloging: Librarianship's Best Bargain," Library Journal 125 (June 1999): 44-46.

49. Hsieh-Yee, "Cataloging and Metadata Education in North American LIS Programs."

50. Wilder, "Demographic Trends Affecting Professional Technical Services Staffing in ARL Libraries." 